\title{
Development of surfactant-coated alginate capsules containing Lactobacillus plantarum
}

Article

Accepted Version

Creative Commons: Attribution-Noncommercial-No Derivative Works 4.0

Albadran, H. A., Chatzifragkou, A., Khutoryanskiy, V. and Charalampopoulos, D. (2018) Development of surfactantcoated alginate capsules containing Lactobacillus plantarum. Food Hydrocolloids, 82. pp. 490-499. ISSN 0268-005X doi: https://doi.org/10.1016/j.foodhyd.2018.04.035 Available at https://centaur.reading.ac.uk/76851/

It is advisable to refer to the publisher's version if you intend to cite from the work. See Guidance on citing.

To link to this article DOI: http://dx.doi.org/10.1016/j.foodhyd.2018.04.035

Publisher: Elsevier

All outputs in CentAUR are protected by Intellectual Property Rights law, including copyright law. Copyright and IPR is retained by the creators or other copyright holders. Terms and conditions for use of this material are defined in the End User Agreement.

www.reading.ac.uk/centaur 
Central Archive at the University of Reading

Reading's research outputs online 
2

3 Hanady A. Albadran ${ }^{\mathrm{a}}$, Afroditi Chatzifragkou ${ }^{\mathrm{a}}$, Vitaliy V. Khutoryanskiy ${ }^{\mathrm{b}^{*}}$, Dimitris

4 Charalampopoulos ${ }^{\mathrm{a}^{*}}$

5

6 aDepartment of Food and Nutritional Sciences, University of Reading, Whiteknights, PO Box 226,

7 Reading RG6 6AD, United Kingdom

8

$9 \quad{ }^{b}$ Reading School of Pharmacy, University of Reading, Whiteknights, PO Box 224, Reading RG6 10 6AD, United Kingdom

*Corresponding authors:

13 Prof Vitaliy V. Khutoryanskiy, Reading School of Pharmacy, University of Reading, Whiteknights, 14 PO Box 224, Reading RG6 6AD, United Kingdom, Email: v.khutoryanskiy@reading.ac.uk, Tel.: $15+44(0) 1183786119$

16 17

Prof Dimitris Charalampopoulos, Department of Food and Nutritional Sciences, University of 18 Reading, Whiteknights, PO Box 226, Reading RG6 6AD, United Kingdom, Email: 19 d.charalampopoulos@ reading.ac.uk, Tel.: +44 (0) 1183788216 
Abstract

A novel concept is proposed in which alginate capsules containing a model probiotic Lactobacillus plantarum strain are coated with different surfactants with the aim to enhance cell survival during passage initially through simulated gastric (SGF) and then intestinal (SIF) fluid. The surfactants investigated included the anionic sodium dodecyl sulphate (SDS) and ammonium lauryl sulphate (ALS), the cationic dimethyldioctadecylammonium chloride (DDAC), benzalkonium chloride (BZK) and hexadecyltrimethylammonium bromide (CTAB), and the zwitterionic lecithin. Coating the alginate capsules with CTAB, BZK, ALS and SDS resulted in worst survival ( 4-9 log CFU/g decrease) compared to uncoated capsules ( 3 log CFU/g decrease), after 1 hour exposure to SGF and two hours in SIF, which was most likely associated with their gradual penetration inside the microcapsules, as shown by confocal microscopy, and their antimicrobial effects. Coating the alginate capsules with DDAC improved cell survival compared to uncoated capsules $(\sim 1.2 \mathrm{CFU} / \mathrm{g}$ decrease), whereas coating with lecithin improved cell survival considerably, resulting in almost complete recovery of viable cells in SGF and SIF ( $0.3 \log$ CFU/g decrease). Although the interaction between alginate and lecithin was relatively weak as demonstrated by turbidity and contact angle measurements, it is likely that the protection was associated with the fact that lecithin was able to penetrate into the capsule rapidly, an observation that was supported by the fact that lecithin enhanced the viability of free cells in SGF and SIF. Lecithin has significant potential of being used as a coating material for probiotic containing capsules.

Keywords: probiotic, Lactobacillus plantarum, capsule, surfactants, lecithin, coating 


\section{Introduction}

Encapsulation of probiotic bacteria can be used in order to protect the cells from harmful conditions that can affect their viability, i.e. within a food product or during passage through the gastrointestinal tract (GIT). The effectiveness of encapsulation depends on the method used (e.g. extrusion, emulsification, spray drying), the type and concentration of the matrix encapsulation materials and the presence of a coating layer (Cook, Tzortzis, Charalampopoulos, \& Khutoryanskiy, 2012; Martin, Lara-Villoslada, Ruiz, \& Morales, 2015; Chen, Wang, Liu, \& Gong, 2017; Simoes et al., 2017). Alginate, an anionic linear polysaccharide comprising of (1-4)-linked $\beta$-D-mannuronic acid and $\alpha$-L-guluronic acid residues, has been used widely as a matrix encapsulation material (Cook, Tzortzis, Charalampopoulos, \& Khutoryanskiy, 2011; Zhao et al., 2017, Zheng et al., 2017). Moreover a number of polysaccharides and proteinaceous materials have been investigated as coating materials of the capsules with the view to enhance cell protection, as it has been shown that even if encapsulation enhances the survival rate of probiotics, this does not immediately imply that the functional survival is also increased (de Vos et al., 2010). The focus has mainly been on chitosan, a cationic linear amino-polysaccharide consisting of (1-4)-linked $\beta$-D-glucosamine and Nacetyl-D-glucosamine residues (Hejazi \& Amiji, 2003; Trabelsi et al., 2013; Abbaszadeh, Gandomi, Misaghi, Bokaei, \& Noori, 2014), but also gelatine and glucomannan (Nualkaekul, Cook, Khutoryanskiy, \& Charalampopoulos, 2013), poly-L-lysine (Ding \& Shah, 2009) and whey proteins (Gbassi, Vandamme, Ennahar, \& Marchioni, 2009) have been investigated. Along with the protection that such coatings can offer to the microorganisms, other beneficial properties may also be imparted, such as giving greater control over bacterial release in the GIT (Cook et al., 2012).

Surfactants are surface-active materials that have the ability to reduce the surface tension of a liquid and have found numerous applications as detergents, wetting agents, emulsifiers, foaming agents and dispersants in food, pharmaceuticals, cosmetic and personal care formulations. All surfactants contain two parts, the tail (hydrocarbon chain) which has hydrophobic properties and the head group that carries the charge (positive, negative or both), and are classified according to their charge, as anionic, cationic, zwitterionic and non-ionic (Schramm, Stasiuk, \& Marangoni, 2003). Depending on their structure (e.g. length of hydrophobic part, charge) and their concentration, surfactants can also have antimicrobial properties, primarily antibacterial (Xia, Xia, \& Nnanna, 1995; Ishikawa, Matsumura, Katoh-Kubo, \& Tsuchido, 2002; Joondan, Jhaumeer-Laulloo, \& Caumul, 2014; Pinazo et al., 2016). Surfactants can interact with the materials used as matrix encapsulation materials, such as carbohydrates or proteins, and can therefore play the role of a coating material for capsules, a novel concept proposed through this work. A few studies have been conducted investigating the interactions between surfactants and polysaccharides, such as alginate, using a variety of techniques 
including turbidity, isothermal titration calorimetry (Bonnaud, Weiss, \& McClements, 2010), smallangle neutron scattering, rheology (Bu, Kjoniksen, Elgsaeter, \& Nystrom, 2006) and fluorescence spectroscopy (Neumann, Schmitt, \& Iamazaki, 2003). It was shown that the interactions are of both hydrophobic and ionic nature, the level and extent of which depends on the structure and hydrophilic/hydrophobic characters of both the surfactant and the carbohydrate, a fact that emphasises the importance of selecting appropriate combinations for specific applications.

Over the last few years there have been a small number of studies in which different surfactants (primarily lecithin) were added into the polysaccharide-based matrix for the encapsulation of probiotic bacteria, using the emulsification technique coupled with internal or external gelation. In the study by Donthidi, Tester, \& Aidoo (2010) it was demonstrated that when lecithin was used as a co-encapsulation material with alginate and starch, the survival of Lactobacillus casei was significantly increased during 12 weeks storage at $23{ }^{\circ} \mathrm{C}$ in dried form, as well as in yoghurt during storage 28 days at $4{ }^{\circ} \mathrm{C}$. It was also shown that by incorporating lecithin vesicles to the wall material of alginate-chitosan capsules the survival of Lactobacillus and Bifidobacterium strains in model gastrointestinal solutions was considerably improved (Chen, Cao, Ferguson, Shu, \& Garg, 2012a; Zhao, Ferguson, Shu, Weir, \& Garg, 2012b). According to some recent studies the type and concentration of surfactant will influence the production yield as well as the size, shape and mechanical properties of the produced probiotic containing capsules (Lupo, Maestro, Porras, Gutierrez, \& Gonzalez, 2014; Banerjee, Chowdhury, \& Bhattacharya, 2017; Huq et al., 2017; Zaeim, Sarabi-Jamab, Ghorani, Kadkhodaee, \& Tromp, 2017). However, no studies have been reported investigating the interactions between carbohydrate polymers and surfactants when the latter are utilised as coating materials, and how these interactions influence the protection of encapsulated probiotic bacteria during their passage through gastrointestinal tract.

The aim of this study was to investigate different types of surfactants as coating materials for alginate capsules containing L. plantarum, including anionic surfactants (sodium dodecyl sulphate and ammonium lauryl sulphate), cationic (dimethyldioctadecylammonium chloride, hexadecyltrimethylammonium bromide, benzalkonium chloride) and zwitterionic (lecithin). The objectives were to study the physicochemical interactions between the alginate capsule and the surfactants, and investigate the mechanisms through which the surfactant coated capsules can offer additional protection to the cells against the adverse conditions of the gastrointestinal tract.

\section{Materials and Methods}

\subsection{Materials}


Lactobacillus plantarum NCIMB 8826 was obtained from the UK National Collection of Industrial and Marine Bacteria (NCIMB). MRS broth and agar and phosphate buffer saline (PBS) were obtained from Oxoid. Sodium alginate (19-40 kDa), dimethyldioctadecylammonium chloride (DDAC), hexadecyltrimethylammonium bromide (CTAB), benzalkonium chloride (BZK), ammonium lauryl sulphate (ALS), sodium dodecyl sulphate (SDS), Nile Red (for microscopy) and glycerol, pepsin (from porcine) and pancreatin lipase were purchased from Sigma-Aldrich. L-alphalecithin was purchased from ACROS Organics. Glacial acetic acid 96\% (v/v), sodium chloride and sodium hydroxide were obtained from Fisher Scientific. Calcium chloride dihydrate was purchased from VWR International.

\subsection{Methods}

\subsubsection{Preparation of microbial culture}

L. plantarum NCIMB 8826 was maintained in $20 \%(\mathrm{w} / \mathrm{v})$ glycerol suspension at $-18{ }^{\circ} \mathrm{C}$ in $1.8 \mathrm{~mL}$ cryo-vials. Upon thawing of a cryo-vial, a cell aliquot was cultivated in $100 \mathrm{~mL}$ of MRS broth at $200 \mathrm{rpm}$ and $37^{\circ} \mathrm{C}$ for 16 hours until the optical density measured at $600 \mathrm{~nm}$ was approximately 0.85 . The cells were harvested by centrifugation for 15 minutes at $3200 \mathrm{~g}$. The pellets were washed once using 0.1 M PBS and re-suspended in $100 \mathrm{~mL}$ of PBS, yielding a cell suspension with a concentration of around $\log 10.5 \mathrm{CFU} / \mathrm{mL}$, determined by the spread plate method using MRS agar after incubation $\left(2\right.$ days at $\left.37^{\circ} \mathrm{C}\right)$.

\subsubsection{Antimicrobial effects of surfactants towards $L$. plantarum}

The following method was used to assess the antimicrobial activity of the surfactants. Solutions of $0.05 \mathrm{~g} / \mathrm{L}$ of each surfactant were prepared at $\mathrm{pH} \sim 7$, except lecithin which was dissolved in acetic acid and the $\mathrm{pH}$ was adjusted to 8 . Subsequently, $1 \mathrm{~mL}$ of cell suspension was added to $9 \mathrm{~mL}$ of the surfactant solution and the mixture was incubated at $37{ }^{\circ} \mathrm{C}$. The concentration of bacterial cells was measured at 0, 30, 60 and 120 minutes by sampling $1 \mathrm{~mL}$ from the suspension and centrifuging at 10,000 rpm for 10 minutes. The supernatant was collected and $1 \mathrm{~mL}$ of PBS was added. After appropriate dilution of the suspension, an aliquot of $0.1 \mathrm{~mL}$ was spread on MRS agar and the plates incubated at $37{ }^{\circ} \mathrm{C}$ for 2 days. Bacterial colonies were counted and expressed as $\mathrm{CFU} / \mathrm{mL}$. The experiments were performed in triplicate.

\subsubsection{Preparation of capsules}

The extrusion technique was used for the preparation of capsules. Alginate solution (2\% w/v) [19$40 \mathrm{kDa}$ ) (SAFC, UK) (viscosity: 15-20 cP, $1 \%$ in $\mathrm{H}_{2} \mathrm{O}$ (L); ratio of mannuronic acid:guluronic acid: $3.3 \pm 0.3]$ was prepared and sterilised using a $0.2 \mu \mathrm{m}$ Minisart microfilter (Sartorius Stedim 
Biotech). Loaded capsules (with bacterial cells) were prepared by mixing $9 \mathrm{~mL}$ of alginate solution with $1 \mathrm{~mL}$ of cell suspension. The mixture was passed through a syringe with a 21 gauge needle (BD Precisionglide ${ }^{\circledR}$, Sigma-Aldrich) and extruded manually into a $\mathrm{CaCl}_{2}(0.15 \mathrm{M}, 100 \mathrm{~mL})$ presterilised solution $\left(121^{\circ} \mathrm{C}\right.$ for 15 minutes). Upon extrusion, the capsules were formed and were left in the solution for 30 minutes to harden in accordance to previous studies (Cook, Tzortzis, Khutoryanskiy, \& Charalampopoulos, 2012). The initial cell concentration in $1 \mathrm{~g}$ of capsules (approximately 50 capsules) was around $\log 9.0 \mathrm{CFU} / \mathrm{g}$.

\subsubsection{Coating of capsules with surfactants}

All surfactants were used in concentrations below their critical micelles concentration (CMC) (Table 1), as within that range surfactants exist in the form of monomers whereas as above CMC they form micelles. For the preparation of the surfactant solutions, $0.05 \mathrm{~g}$ of DDAC, CTAB, BZK, ALS and SDS was dissolved in $1000 \mathrm{~mL}$ of water to prepare coating solutions at $\mathrm{pH} \sim 7$. At that $\mathrm{pH}$, DDAC, CTAB and BZK had a cationic character, whereas ALS and SDS served as anionic surfactants. On the other hand, lecithin was dissolved in $0.1 \mathrm{M}$ acetic acid and the $\mathrm{pH}$ was adjusted to 8.0 using $1 \mathrm{M} \mathrm{NaOH}$ (to help lecithin to dissolve); at that $\mathrm{pH}$ lecithin should behave more as an anionic surfactant. All these solutions were sterilised using a $0.2 \mu \mathrm{m}$ Minisart microfilter (Sartorius Stedim Biotech). Loaded capsules (formed as described above) were introduced into $15 \mathrm{~mL}$ of surfactant solution and the mixture stirred for 30,60, 120 minutes at $50 \mathrm{rpm}$. The capsules were collected by filtration and washed with deionised water before use.

Table 1 Surfactants used in the study

\begin{tabular}{|c|c|c|c|c|c|}
\hline Surfactant & Acronym & Structure & Charge & $\begin{array}{l}\text { CMC } \\
(\mathrm{g} / \mathrm{L})\end{array}$ & Reference \\
\hline Lecithin & LEC & & Zwitterionic & 0.61 & $\begin{array}{l}\text { Bustamante, } \\
\text { Gonzalez, } \\
\text { Cartes, \& } \\
\text { Diez (2011) }\end{array}$ \\
\hline $\begin{array}{l}\text { Dimethyldioctadecylammo } \\
\text { nium chloride }\end{array}$ & DDAC & & Cationic & 0.36 & $\begin{array}{l}\text { Han ,Yang, } \\
\text { Liu, Wang, } \\
\& \text { Gao } \\
(2015)\end{array}$ \\
\hline $\begin{array}{l}\text { Hexadecyl trimethyl } \\
\text { ammonium bromide }\end{array}$ & CTAB & & Cationic & 0.29 & $\begin{array}{l}\text { Bahri et al., } \\
(2006)\end{array}$ \\
\hline Benzalkonium chloride & BZK & & Cationic & 0.20 & $\begin{array}{l}\text { Deutschle, } \\
\text { Porkert, } \\
\text { Reiter, }\end{array}$ \\
\hline
\end{tabular}




\begin{tabular}{|l|l|l|l|l|l|}
\hline & & & & & $\begin{array}{l}\text { Keck, \& } \\
\text { Riechelmann } \\
\text { (2006) }\end{array}$ \\
\hline Ammonium lauryl sulphate & ALS & Anionic & 2.34 & $\begin{array}{l}\text { Williams, } \\
\text { Phillips, \& } \\
\text { Mysels } \\
(1955)^{*}\end{array}$ \\
\hline Sodium dodecyl sulphate & SDS & & $\begin{array}{l}\text { Bahri et al., } \\
(2006)\end{array}$ \\
\hline
\end{tabular}

175

\subsubsection{Measurement of capsule size}

The Image $\mathbf{J}$ software was used to measure the size of the capsules in images taken by the microscope system (LEICA E Z4D) after exposing the capsules to the surfactant solution for 30 min. Since the shape of the capsules was regular, the size was determined using the average of 3 different diameters. To ensure better accuracy, for each batch of capsules the measurements were repeated 3 times using different capsules.

\subsubsection{Contact wetting angles of alginate films coated with surfactants}

Contact wetting angles were used to evaluate the hydrophobicity of calcium alginate before and after treatment with the surfactant solution at different exposure times. Firstly, calcium alginate film was prepared using a chromatography paper; the paper was cut in $5.5 \times 7.0 \mathrm{~cm}$ pieces and immersed in $0.15 \mathrm{M} \mathrm{CaCl}_{2}$. Three millilitres of sodium alginate were added on top of the paper using a syringe and the paper was left to stand for 5 minutes. Then, the paper was covered with $30 \mathrm{~mL}$ of $\mathrm{CaCl}_{2}$ $(0.15 \mathrm{M})$ and left overnight at room temperature. The alginate films formed were immersed in 45 $\mathrm{mL}$ of $0.05 \mathrm{~g} / \mathrm{L}$ surfactant solution and the suspension was shaken at $50 \mathrm{rpm}$ for 30,60 and 120 min. The concentration of the surfactant used was similar to that used for coating the capsules $(0.05$ $\mathrm{g} / \mathrm{L})$. Contact wetting angle measurements were recorded using a Theta Lite Optical Tensiometer. Each experiment was performed in triplicate.

\subsubsection{Laser scanning confocal microscopy}

Laser scanning confocal microscopy was performed on the capsules before and after immersing the capsules into different surfactant solutions (lecithin, DDAC, CTAB, BZK, ALS and SDS) for different times (30, 60 and 120 min). A Nikon A1- R confocal microscope was used; an emission wavelength of $595 \mathrm{~nm}$ and an excitation wavelength of $561 \mathrm{~nm}$ along the Z-axis were used to detect the surfactant after staining with Nile Red dye (Greenspan, Mayer, \& Fowler 1985). One hundred microliters of Nile Red dye were added to a single capsule, the capsule was then washed with 
deionized water and placed in a petri dish for image capture; images were captured with a PF lens with a $10 \mathrm{x}$ magnification.

\subsubsection{Viability of encapsulated L. plantarum in simulated gastrointestinal solutions}

The viability (expressed as CFU/g) of encapsulated cells was measured after encapsulation, after treating the capsules with surfactants for 30, 60 and $120 \mathrm{~min}$, and in simulated gastric (SGF) and intestinal fluid (SIF) by the spread plate method.

To measure the cell viability of loaded capsules after encapsulation and surfactant treatment, capsules $(1 \mathrm{~g})$ were collected and blended with $99 \mathrm{~mL}$ PBS in a stomacher (model 400 Circulation, Seward, UK) at $300 \mathrm{rpm}$ for 20 minutes. The cell suspension was then appropriately diluted, spread onto MRS agar plates and the plates incubated for 2 days at $37{ }^{\circ} \mathrm{C}$. Bacterial colonies were counted and expressed as CFU per $\mathrm{g}$.

Simulated gastric fluid (SGF) was prepared $(0.2 \% \mathrm{w} / \mathrm{v} \mathrm{NaCl}, 0.3 \mathrm{~g} / \mathrm{L}$ pepsin) and the $\mathrm{pH}$ was adjusted to 2 by adding $1 \mathrm{M} \mathrm{HCl}$. Simulated intestinal fluid (SIF) was prepared using $0.05 \mathrm{M}$ potassium phosphate buffer $\left(\mathrm{KH}_{2} \mathrm{PO}_{4}\right)$ after adjusting the $\mathrm{pH}$ to 7.2 using $1 \mathrm{M} \mathrm{NaOH}$ and adding $0.125 \mathrm{~g} / \mathrm{L}$ pancreatin lipase. The solutions were sterilised using a $0.2 \mu \mathrm{m}$ Minisart microfilter (Sartorius Stedim Biotech, Germany). One gram of capsules was added to $9 \mathrm{~mL}$ SGF and the viability of encapsulated bacteria was measured after $60 \mathrm{~min}$ and incubation at $37{ }^{\circ} \mathrm{C}$, following the homogenisation and spread plate method described above. After exposure to SGF, the capsules were transferred to $9 \mathrm{~mL}$ of simulated intestinal fluid (SIF) and the viability of the bacterial cells was measured after 60 and $120 \mathrm{~min}$ by taking $1 \mathrm{~mL}$ from the suspension, diluting with $99 \mathrm{~mL}$ PBS, followed by the homogenisation and spread plate method described above.

\subsubsection{Statistical analysis}

The results are reported throughout as mean \pm standard deviation. Statistical analysis of the data was conducted using ANOVA, Version.17 of SPSS. Values $P<0.05$ were considered to be statistically significant.

\section{Results and Discussion}

\subsection{Antimicrobial effects of surfactants}

Initially, the surfactant solutions were evaluated for their potential antimicrobial effects on free $L$. plantarum cells. As shown in Figure 1, both BZK and CTAB (cationic surfactants) exhibited strong antimicrobial properties as no live bacteria were detected after $30 \mathrm{~min}$ of incubation. On the other 
hand, incubation of free L. plantarum cells in lecithin did not affect the viability of the bacterial cells significantly $(P>0.05)$ compared to the control. The viability of $L$. plantarum in the presence of DDAC, SDS and ALS decreased significantly $(P<0.05)$ compared to the control, although the decrease was less than $0.5 \log$.

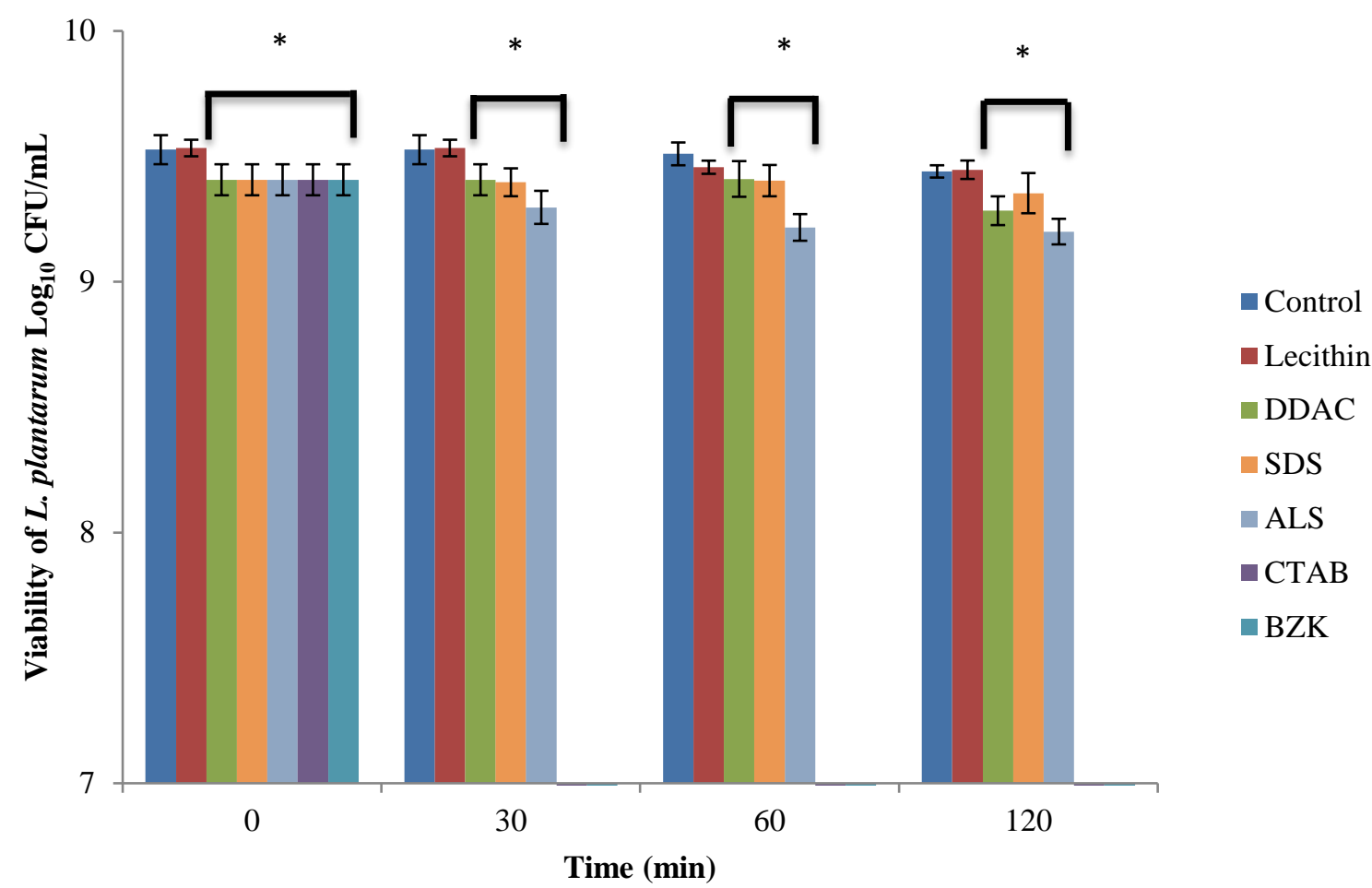

Figure 1 Antimicrobial effect of surfactants on free L. plantarum cells after exposure for 0, 30, 60 and 120 minutes in solutions containing $0.05 \mathrm{~g} / \mathrm{L}$ of surfactant (DDAC, SDS, ALS, CTAB, BZK) at $\mathrm{pH} 7$, and $\mathrm{pH} 8$ in the case of lecithin. No viable cells were detected in the case of BZK and CTAB (cell concentration $<2 \log \mathrm{CFU} / \mathrm{mL})$. ${ }^{*}$ Indicates significant difference $(P<0.05)$ compared to control.

$\mathrm{CTAB}$ and BZK contain quaternary ammonium group and can act as antimicrobial agents as both of them are positively charged. Labena, Hegazy, Horn, \& Muller (2015) attributed the antimicrobial mechanism of action of cationic surfactants against $S$. aureus to the electrostatic interactions between the anionic lipoproteins of the cell membrane and the hydrophilic head of the cationic surfactant. Moreover, the hydrophobic tail of CTAB and BZK, i.e. the N-alkyl group, penetrates inside the bacteria, which results in changes in the lipid bilayer of the cell membrane, particularly of Gram positive bacteria such as S. aureus, causing the leakage of intracellular fluid, and leading eventually to cell death (Ioannou, Hanlon, \& Denyer, 2007). Interestingly, DDAC did not affect cell viability in SIF, which is surprising considering the cationic character of this surfactant. 
259 On the other hand, the antimicrobial effect of anionic surfactants, such as SDS and ALS, against 260 Gram positive bacteria is likely to involve the interaction of the surfactant with the phospholipid 261 cell membrane, which leads to membrane disruption and depending on the surfactant concentration 262 to complete membrane solubilisation, as well as to the modification of membrane enzymes and 263 denaturation of membrane proteins (Cords; Burnett, Hilgren, Finley, \& Magnuson, 2005). However, 264 the antibacterial effect depends greatly on the concentration of the surfactant and the $\mathrm{pH}$ of the 265 solution; low concentrations of anionic surfactants (much lower than CMC) result in low 266 antibacterial effect, while as the acidity increases $(\mathrm{pH}<3.5)$ the antibacterial effect increases 267 (Cozolli, 1997). The low surfactant concentrations used in this experiment $(0.05 \mathrm{~g} / \mathrm{L})$ as well as the 268 high $\mathrm{pH}$ of the solutions $(\mathrm{pH} \sim 7)$ is probably the reasons for the relatively small decrease in the 269 viability of the cells in the case of SDS and ALS.

\subsection{Hydrophobicity of alginate films coated with surfactants}

273 Calcium alginate films were prepared and were immersed in the different surfactants for various times (30 to 120 minutes). Subsequently the coated films were treated with water and the wettability of the surfaces was measured using the contact angle method, to identify any differences in the hydrophobicity of alginate films after coating with surfactants (Figure 2). When the contact angle of the water drop on the surface is less than $20^{\circ}$, the surface is considered to be mostly hydrophilic, while a typical hydrophobic surface will display contact angle values greater than $70^{\circ}$ (Carneiro-daCunha et al., 2010).

Calcium alginate surface treated with water showed a high contact angle of $56.93 \pm 6.03^{\circ}$ (Figure 2b). When calcium alginate was treated for $30 \mathrm{~min}$ with various surfactants, the hydrophobicity decreased in all cases significantly $(P<0.05)$, and in some of them by more than $40 \%$. However, as the time of immersion increased the hydrophobicity for lecithin, DDAC and ALS did not change, however that of $\mathrm{CTAB}$ and BZK increased significantly $(P<0.05)$, and after 120 minutes the hydrophobicity of $\mathrm{CTAB}$ was greater than that of calcium alginate $\left(64.26 \pm 7.34^{\circ}\right)$, whereas in the case of BZK it was similar $\left(56.11 \pm 7.63^{\circ}\right)$. The pattern observed with CTAB and BZK indicates that initially ( $\sim 30$ minutes) there is strong electrostatic interaction between alginate-surfactant which lead to increased turbidity (data not shown) and decreased hydrophobicity (Figure 2), however hydrophobic interactions between the long alkyl chains of CTAB and BZK and the hydrophobic backbone of alginate come into play as time progresses. The pattern observed with the anionic SDS and ALS, i.e. the decrease in hydrophobicity of the surfactant-coated alginate film suggests an increased hydrophilic interaction between these particular surfactants and alginate. This 
has also been suggested by Neumann et al. (2003) investigating the interactions between alginate and various surfactants by fluorescence, who hypothesised that this was due to increased interaction between hydrophilic sulphonate groups (which are present in SDS and ALS) and the hydroxyl groups of alginate.

298

(b)

(a)
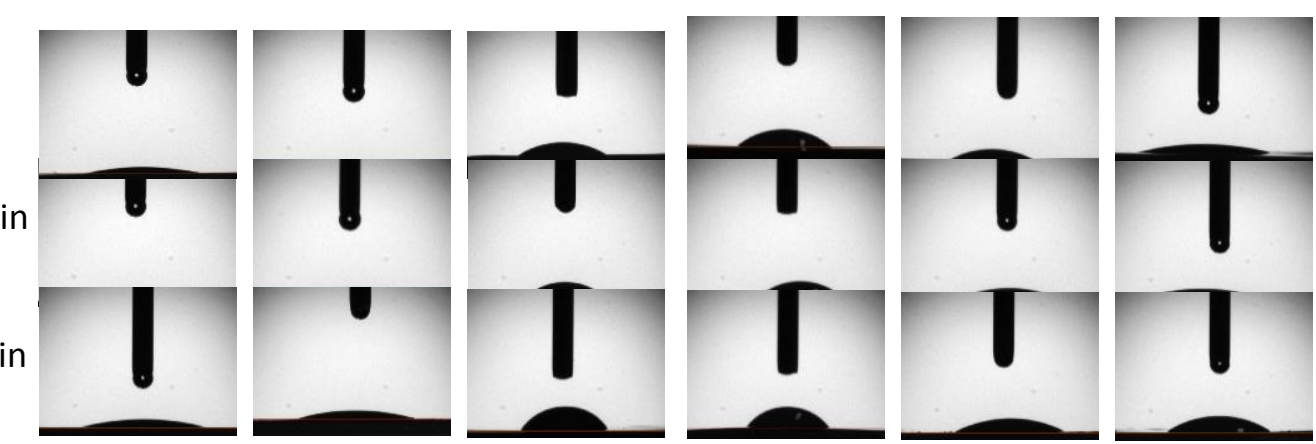

305 306 307 308 309 310 311

(b)

$120 \mathrm{~min}$
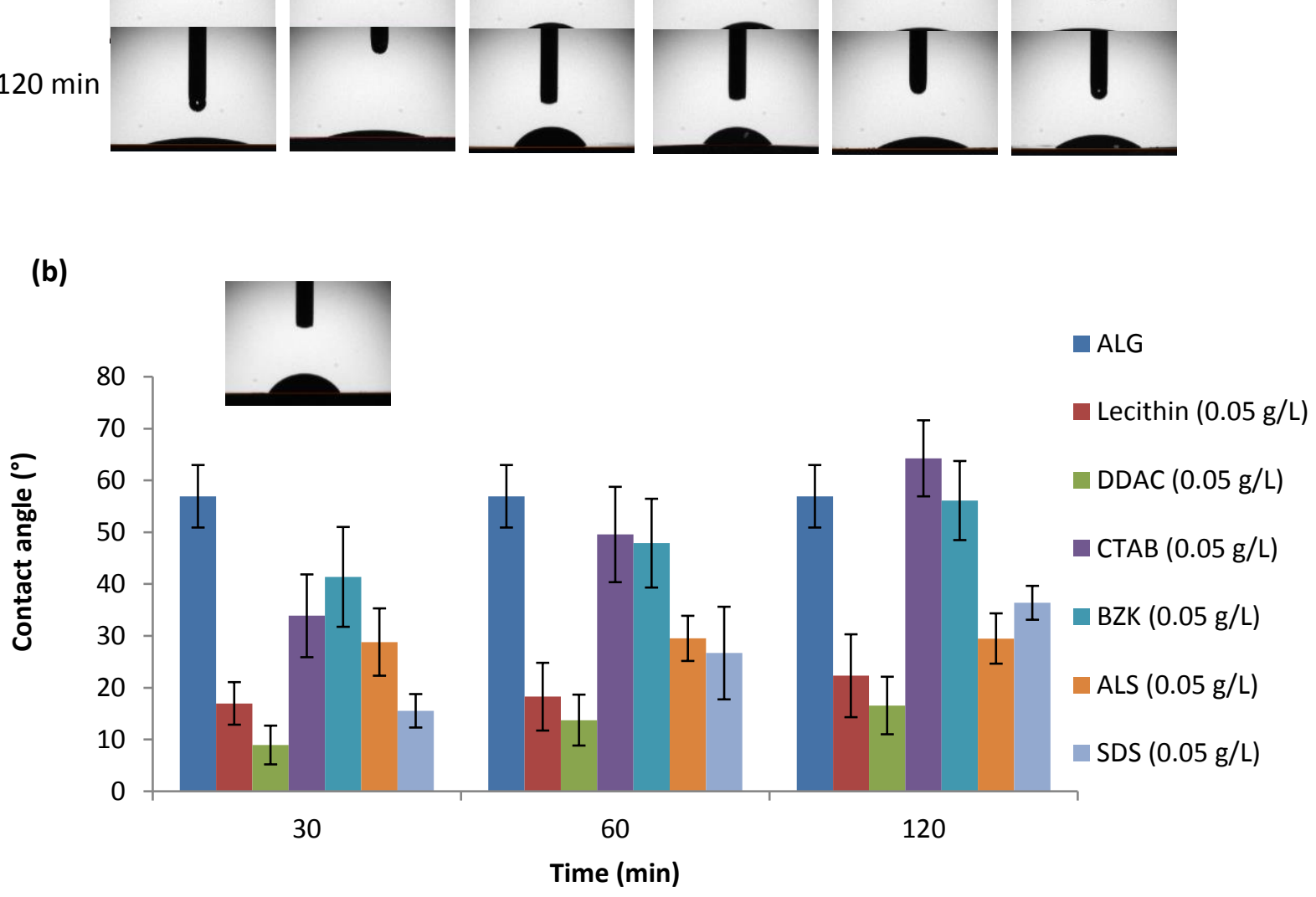

Figure 2 (a) Images showing the wettability of calcium alginate surfaces treated with different surfactants (b) Contact wetting angle measurements of calcium alginate surfaces treated with different surfactants. Data given as mean \pm standard deviation $(n=3)$. The image insert in (b) shows the wetting of untreated calcium alginate surface.

\subsection{Size and swelling of capsules}

In order to understand the possible effect of different surfactants on the size of the capsules, calcium alginate capsules were treated with various surfactants for $30 \mathrm{~min}$. Calcium alginate capsules 327 (control) had a size of $3.26 \pm 0.15 \mathrm{~mm}$. After their exposure to surfactant solutions, in all the cases 328 the size of the capsules did not significantly differ $(P>0.05)$ from that of the control (Figure 3$)$, 
with the exception of lecithin coated capsules, the size of which increased significantly $(P<0.05)$ by around $0.6 \mathrm{~mm}$.

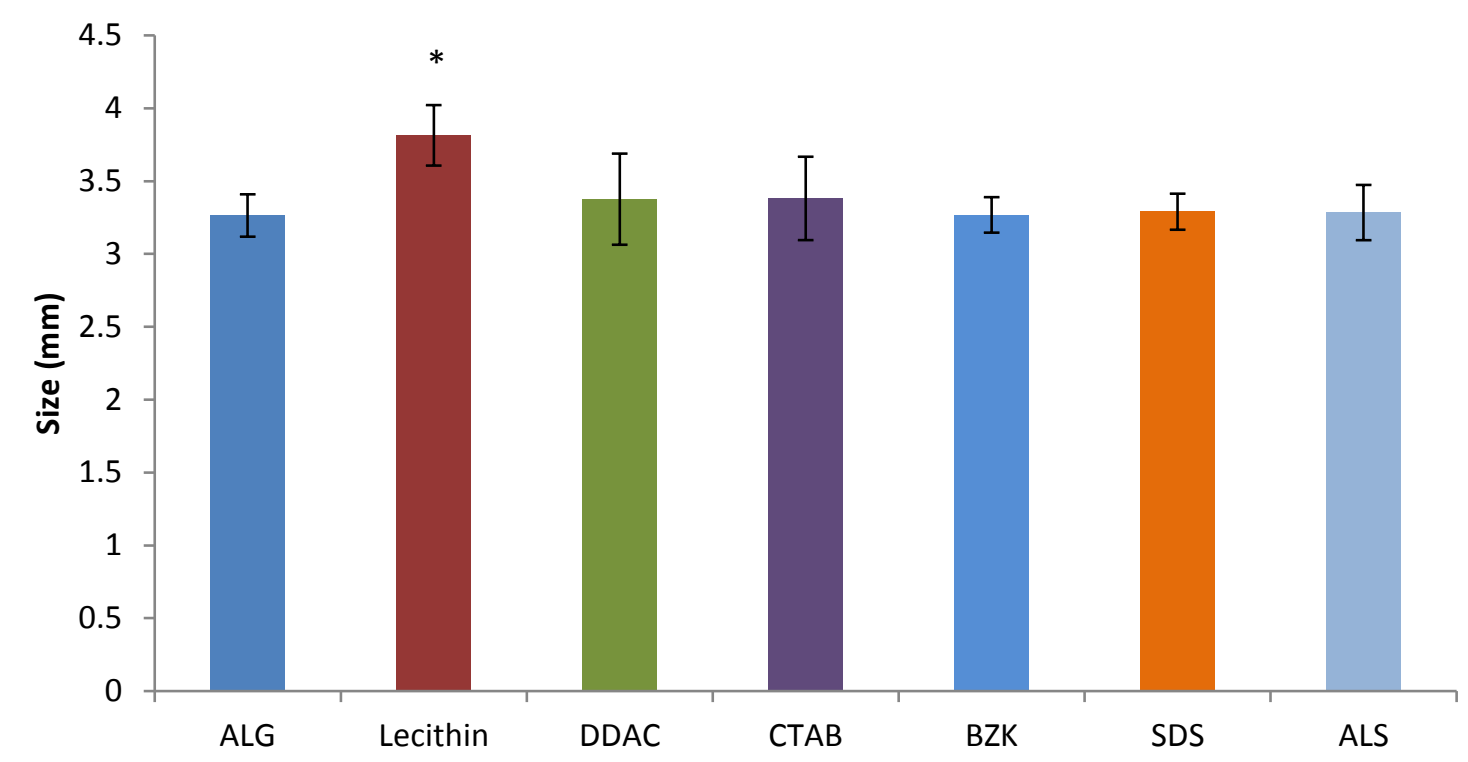

Figure 3 Size of uncoated and surfactant-coated alginate capsules with and without surfactant. Data given as mean \pm standard deviation $(n=5)$.* Indicates significant difference $(P<0.05)$ of the values from the starting control (ALG).

The fact that the size of the capsules did not change in the case of cationic surfactants (DDAC, $\mathrm{CTAB}$ and BZK) is in contrast with previous works. More specifically, in the study by Obeid et al. (2014), the size of alginate capsules upon immersion to cetylpyridinium chloride (CPC), a cationic surfactant, at $\mathrm{pH} 7$ decreased from about $3.3 \mathrm{~mm}$ to around $2.7 \mathrm{~mm}$. This was attributed to the adsorption of CPC, occurring due to both electrostatic interactions and hydrophobic interactions inducing the formation of surfactant aggregates in the capsules. Similar result was also obtained in the study of Wang, Wang, Shi, \& Wang (2013) in which alginate nanocomposite was immersed into $\mathrm{CTAB}$ and dodecyltrimethylammonimum bromide (DTAB); it was observed that the swelling ratio decreased particularly as the surfactant concertation increased. A possible reason for these differences is the fact that the surfactant concentrations used for coating the alginate capsules produced in this study $(0.05 \mathrm{~g} / \mathrm{L})$ were much lower than the CMC of each surfactant (see Table 1) and hence the electrostatic and hydrophobic interactions were significantly lower, leading to less amount of surfactant aggregates being formed onto the capsules. The fact that the size of the capsules was not affected when using ALS and SDS was expected, and is most likely because anionic surfactants are difficult to enter the polymer network due to electrostatic repulsion with the negatively charged carboxylate groups of alginate, as also suggested by Wang et al. (2013). The 
significant increase in size that was observed in the case of lecithin coated capsules indicates increased swelling of the alginate capsules. This could be due to the fact that the polymer network expanded as a result of the increased hydrophilicity of the lecithin coated capsules, as also seen in Figure 2, coupled with the increased electrostatic interaction at $\mathrm{pH} 8$ between alginate, which becomes more ionised (Hua, Ma, Li, Yang, \& Wang, 2010), and the amine group of lecithin.

Laser scanning confocal microscopy was used to examine the structural interactions between the surfactants and alginate capsules. More specifically, the aim was to determine whether the surfactants formed a layer around the capsules, thus acting as a coating material, or whether they were able to penetrate deeply into the matrix of the capsule. The pore size of calcium alginate gel is known to be around 50-200 nm (Cuadros; Erices, \& Aguilera, 2015), whereas Chamieh, Davanier, Jannin, Demarne, \& Cottet (2015) reported that the size of the micelles for some cationic (cetyltrimethylammonium bromide), anionic (sodium dodecyl sulfate, sodium taurocholate) and zwitterionic surfactants (N-dodecyl-N,N-dimethyl-3-ammonio-1-propanesulfonate, 3-(3cholamidopropyl)-dimethyl-ammonio)-propanesulfonate) is between 2.14 and $8.16 \mathrm{~nm}$ in diameter, which indicates that surfactant monomers and micelles should be able to freely diffuse inside the calcium alginate gel. Considering the potential antimicrobial activity of certain surfactants, this knowledge is important for selecting appropriate surfactants for applications aiming to enhance probiotic delivery.

In order to evaluate the above hypothesis, the capsules with and without a surfactant coating were stained with a dye and the fluorescence intensity on the surface and inside the matrix of the capsule monitored using confocal microscopy. Nile Red, a natural non-ionic dye that has the ability to interact with hydrophobic compounds such as fatty acids was selected, as it is able to bind to all types of surfactants (anionic, cationic, zwitterionic and nonionic) (Kundu, Ghosh, Jana, \& Chattopadhyay, 2015). In the absence of surfactant coating, no fluorescence was detected after immersion of the capsules to Nile Red (data not shown). As seen in Figure 4A (1, 2 and 3), calcium alginate capsules treated with lecithin exhibited high fluorescence intensity; it seemed that with increasing the exposure time of capsules to the surfactants (30,60 and $120 \mathrm{~min}$ ) the penetration of lecithin inside the matrix of the capsule increased. DDAC exposed capsules (Figure 4B 1, 2 and 3) exhibited reduced fluorescence compared to lecithin although higher than that observed for CTAB, BZK, ALS and SDS (Figure 4C, D, E and F, respectively); in all cases however penetration of the surfactant into the matrix of the capsules was observed after prolonged exposure (120 min). These images confirmed that surfactants have the ability to penetrate inside the capsules and that the level of penetration increases with time. The increased fluorescence intensity in the case of the cationic 
399 surfactants DDAC, CTAB and BZK, particularly after 120 min of immersion, can be attributed to 400 the electrostatic interaction between alginate and the surfactant, whereas the relatively lower 401 fluorescence intensity in the case the anionic ALS and SDS surfactants to hydrophobic interactions. 402 These visual observations are in accordance with the results from the hydrophobicity study (Figure 403 2). As mentioned in the previous sections, the increased interaction between alginate capsules and 404 lecithin, which led to increase in swelling and to increased fluorescence intensity, can be attributed 405 to the increased hydrophilicity of the lecithin coated capsules coupled with the increased 406 electrostatic interaction at $\mathrm{pH} 8$ between alginate and the amine group of lecithin. The results from 407 confocal microscopy are in accordance with the results of Jana, Ghosh, \& Chattopadhyay (2013), 408 who reported that the interactions of Nile Red with zwitterionic and cationic surfactants were 409 stronger than with anionic surfactants, as shown by fluorescence spectroscopy. 
A

420

$4 z_{1}$

422

423

424

425

426

427

428

429

430

1า1
B
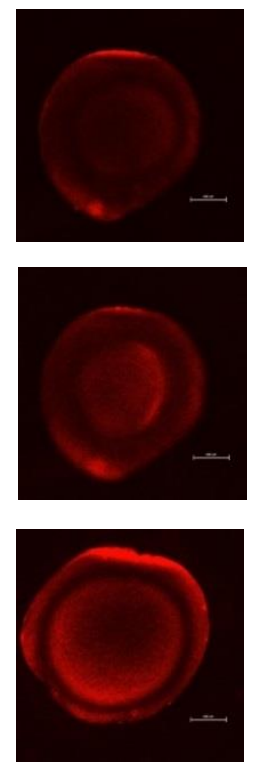

C
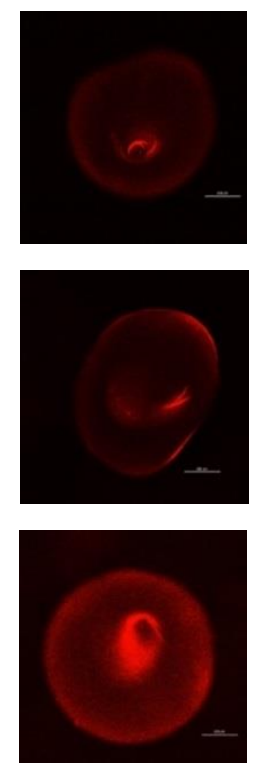

D
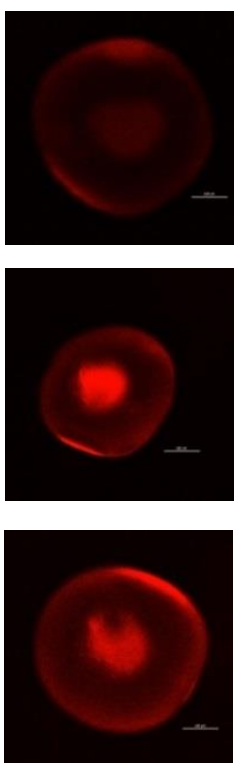

E
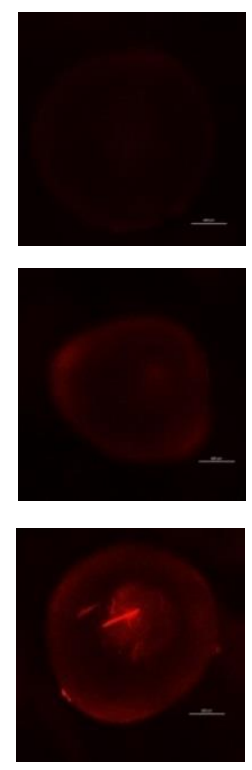

F
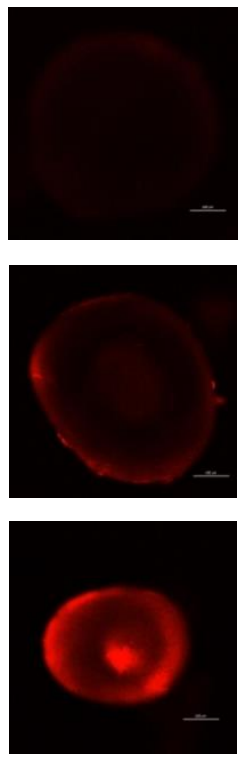

Figure 4 Confocal microscopy images for alginate capsules treated with different surfactants and subsequently immersed into $0.5 \mathrm{mg} / \mathrm{mL}$ Nile red. (A) lecithin, (B) DDAC, (C) CTAB, (D) BZK, (E) ALS and (F) SDS, after (1) 30, (2) 60 and (3) 120 min.

\subsection{Effect of surfactant coating on cell viability}

436 Figure 5 demonstrates the cell viability of L. plantarum cells entrapped in alginate capsules during their exposure for $120 \mathrm{~min}$ in water (control) and $0.05 \mathrm{~g} / \mathrm{L}$ surfactant solutions. The cell concentration of $L$. plantarum in the alginate capsules before exposure was $\sim 9 \log$ CFU/g. Exposing calcium alginate capsules to lecithin, DDAC and ALS for up to 120 min did not affect significantly $(P>0.05)$ the viability of encapsulated bacteria, while exposure to SDS reduced significantly $(P<0.05)$ the viability of encapsulated cells although the decrease was less than $0.5 \log \mathrm{CFU} / \mathrm{g}$. A significant $(P<0.05)$ decrease was observed in the case of BZK and CTAB, which increased with exposure time, resulting in $~ 5.3 \log \mathrm{CFU} / \mathrm{g}$ and $\sim 4.2$ $\log \mathrm{CFU} / \mathrm{g}$, after exposure to the surfactants for $120 \mathrm{~min}$, respectively.

From this experiment, it can be deduced that the surfactants could be divided in two groups, with the first group consisting of lecithin, DDAC, SDS and ALS not affecting considerably cell viability, and the second group consisting of CTAB and BZK exhibiting strong antimicrobial activity and reducing considerably cell viability. Considering these results and comparing with the results with the free cells in the presence of surfactants shown in Figure 1 it can be observed that the alginate capsule reduced the very strong antimicrobial effect of the cationic surfactant $\mathrm{CTAB}$ and $\mathrm{BZK}$. This was probably due to the relatively strong 
453

454

455

456

457

458

459

460

461

462

463

electrostatic interactions of these surfactants with alginate and the hydrophobic character of the alginate-surfactant complex which most likely resulted in a denser polymer network (Figure 2). However, as seen by confocal microscopy (Figure 4), CTAB and BZK after prolonged coating time were able to penetrate to an extent into the capsules where they most likely affected the integrity of the bacterial cell membrane, resulting in cell death. The fact that lecithin, ALS and DDAC did not affect cell viability, whereas SDS had a very small negative effect, is in accordance with the results with the free cells in the presence of surfactants at $\mathrm{pH} 7$ and $\mathrm{pH} 8$ for lecithin (Figure 1). It must be noted that in previous studies, when lecithin was used as a component of the matrix to encapsulate probiotic bacteria, an improvement in cell viability in simulated gastrointestinal conditions, i.e. low $\mathrm{pH}$ and high bile salt concentrations was reported (Donthidi et al., 2010, Chen et al., 2012b).

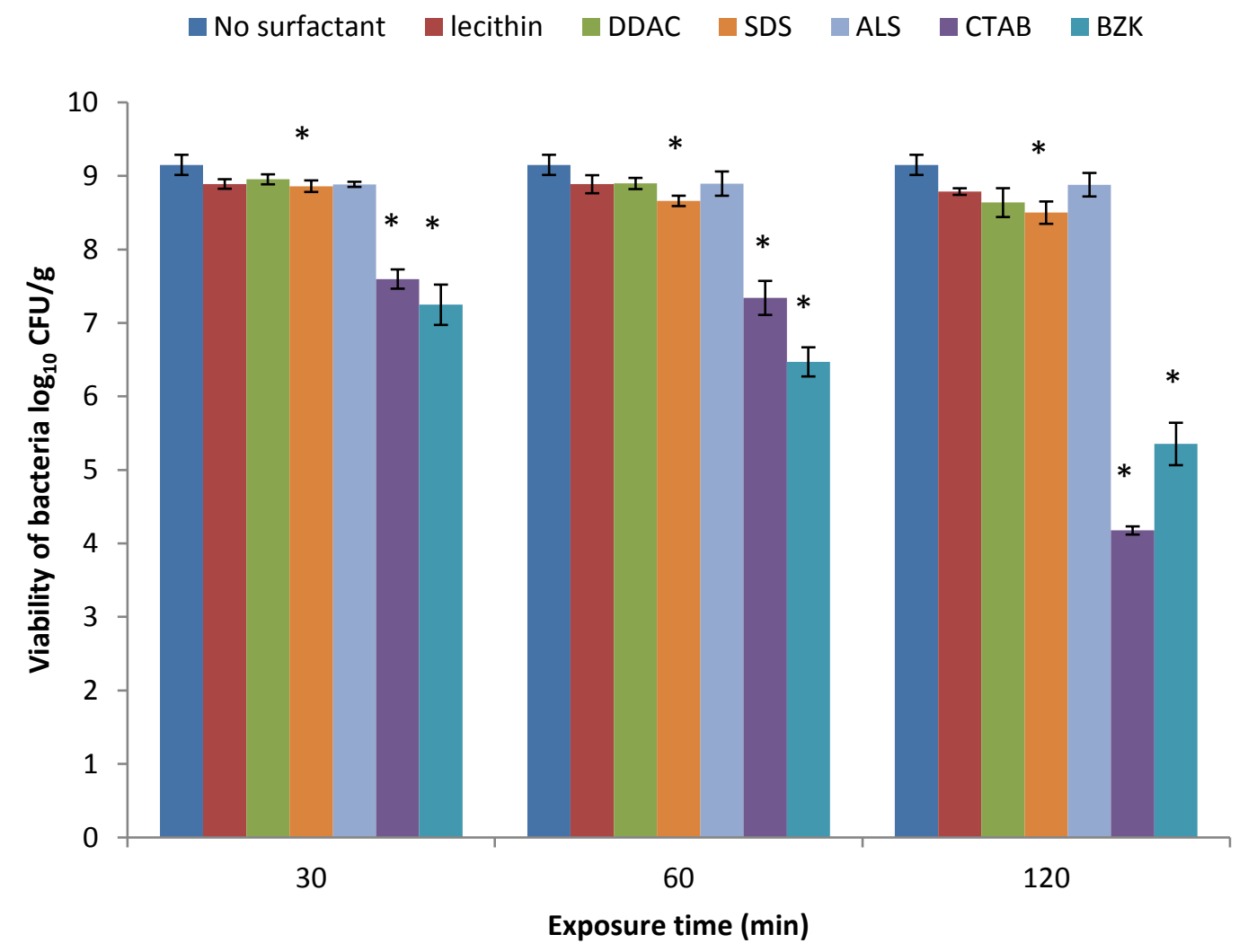

Figure 5 Cell viability of $L$. plantarum cells in alginate capsules during their exposure for $120 \mathrm{~min}$ in water (control) and $0.05 \mathrm{~g} / \mathrm{L}$ surfactant solutions at $\mathrm{pH} 7$ and at $\mathrm{pH} 8$ in the case of lecithin. Data given as mean \pm standard deviation $(n=3)$. ${ }^{*}$ Indicates significant difference $(P$ $<0.05$ ) of the values from the no surfactant. The cell concentration of L. plantarum in the alginate capsules before exposure (time $0 \mathrm{~min}$ ) was $9.00 \pm 0.12 \log \mathrm{CFU} / \mathrm{g}$. 


\subsection{Behaviour of probiotic containing capsules in simulated gastrointestinal fluids}

The purpose of this experiment was to evaluate the potential protective effect of the surfactants on cell survival during passage of the probiotic containing capsules through simulated gastrointestinal conditions, consisting of simulated gastric fluid (SGF) at $\mathrm{pH} 2$ and simulated intestinal fluid (SIF) at $\mathrm{pH}$ 7.2; the capsules, both non-coated (control) and surfactant coated alginate capsules were exposed in SGF for $60 \mathrm{~min}$ and subsequently in SIF for 120 min (Figure 6). The capsules did not dissolve in SGF; however all of them were completely dissolved in SIF. The insolubility in SGF is related to the formation of acid alginate gel that is enhanced by increasing the concentration of $\mathrm{H}^{+}$(Cook et al., 2011). Pasparakis \& Bouropoulos (2006) showed that the protonation of carboxylic groups under acidic conditions decreases the electrostatic repulsion and this is responsible for the shrinkage of calcium alginate capsules at $\mathrm{pH}$ 2. However, the presence of $\mathrm{Na}^{+}$in $\mathrm{SIF}$ and the neutral $\mathrm{pH}$ ( $\mathrm{pH}$ 7.2) caused the ionic replacement of $\mathrm{Ca}^{++}$in the structure of calcium alginate which eventually led to $\mathrm{Ca}^{++}$leaching out of the gel and to the degradation of the capsules (Bajpai \& Sharma, 2004).

The viability of L. plantarum in non-coated alginate capsules (control) decreased from $9.00 \pm$ 0.11 to $6.16 \pm 0.26 \log \mathrm{CFU} / \mathrm{g}$ after $60 \mathrm{~min}$ of exposure to SGF. Coating of the capsules with lecithin improved considerably cell survival compared to the control, resulting in a cell concentration of $8.68 \pm 0.025 \log \mathrm{CFU} / \mathrm{g}$ after $60 \mathrm{~min}$ in SGF. When DDAC was used, the cell concertation after 60 min exposure in SGF was higher than the control $(7.84 \pm 0.17 \log$ $\mathrm{CFU} / \mathrm{g})$. All other surfactants (CTAB, BZK, SDS and ALS) demonstrated worst cell survival in SGF compared to the control, indicating that the strong interactions between anionic alginate and the cationic surfactants CTAB and BZK did not enhance the protection offered by the alginate gel in SGF. As mentioned before, the pore size of calcium alginate gel was larger than the size of the micelles of the surfactants, which allows the surfactants to penetrate inside the capsules easily, as also seen in Figure 5, and exerts their strong antimicrobial properties, causing bacterial death. It is interesting to note that although SDS and ALS did not exert an antimicrobial effect at pH 7 (Figure 1), it did in SGF (Figure 6), indicating that the $\mathrm{pH}$ influences considerably the antimicrobial properties of these particular surfactants. In SIF, the capsules rapidly dissolved and thus the surfactants were able to act on the free cells, which was the reason for the dramatic decrease in cell concentration to undetectable levels $(<2 \log$ CFU/g). In SIF, the lecithin coated capsules offered considerable protection to the cells as the cell concentration was $8.7 \mathrm{log}$ CFU/g after $120 \mathrm{~min}$ exposure (i.e 

concertation was around $7.6 \log \mathrm{CFU} / \mathrm{g}(\sim 1.4 \log \mathrm{CFU} / \mathrm{g}$ decrease $)$.

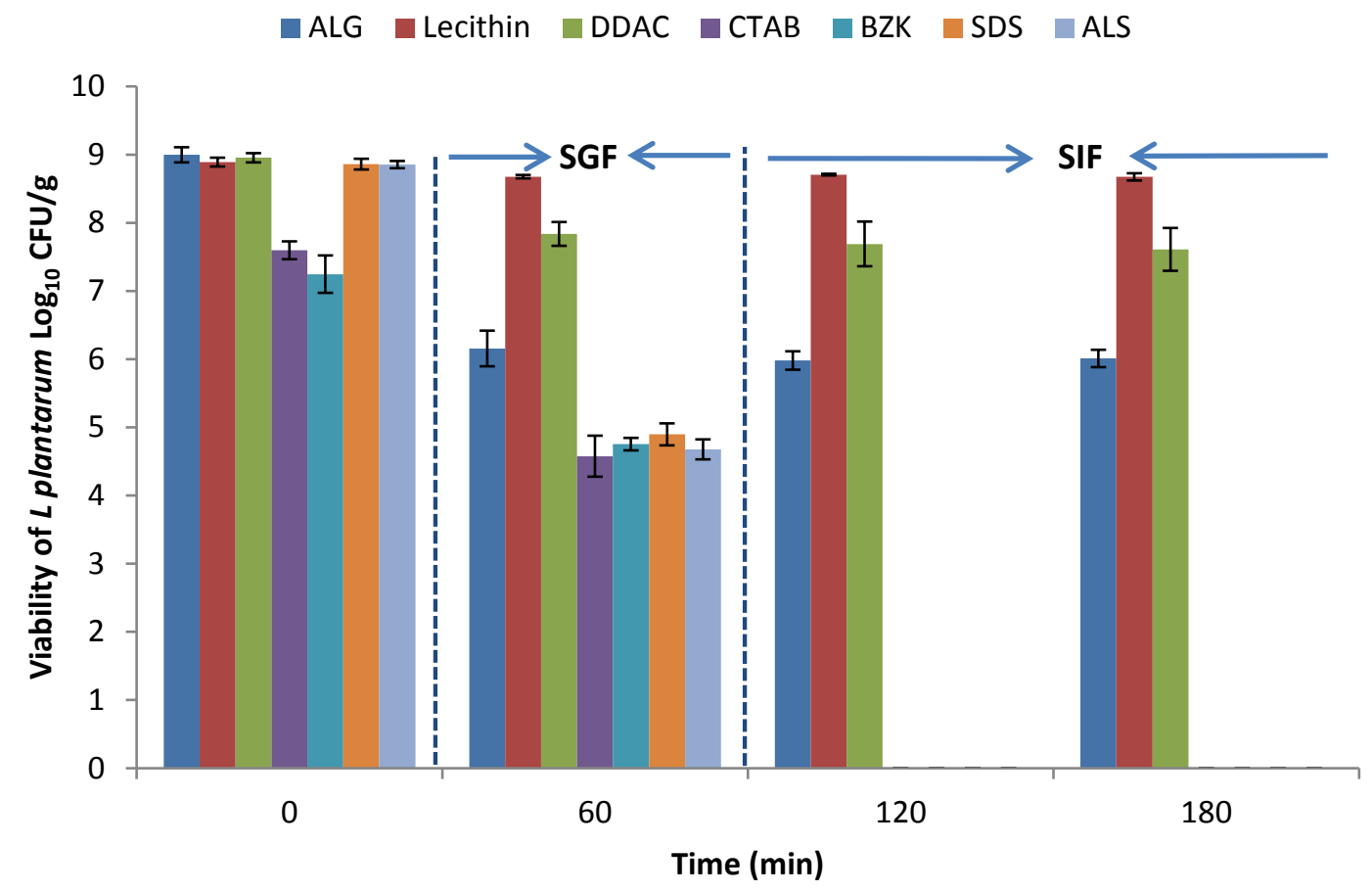

506

Figure 6 Viability of L. plantarum in calcium alginate capsules with and without surfactant coating during exposure to simulated gastric fluid (SGF) at $\mathrm{pH} 2$ for $60 \mathrm{~min}$ followed by exposure to simulated intestinal fluid (SIF) at $\mathrm{pH} 7.2$ for up to $120 \mathrm{~min}$. No viable cells were detected in SIF in the case of the BZK, CTAB, SDS and ALS (cell concentration < 2 log $\mathrm{CFU} / \mathrm{mL})$. Data given as mean \pm standard deviation $(n=3)$.

In order to evaluate the contribution of the coating layer in the case of the lecithin and DDAC coated capsules towards cell protection in SGF and SIF, an experiment was conducted in which free L. plantarum cells were incubated in SGF and SIF in the presence and absence of lecithin and DDAC (Figure 7). It can be observed that lecithin improved significantly the survival of free cells in SGF and SIF compared to free cells without lecithin. Interestingly, in the presence of lecithin no significant $(P>0.05)$ decrease in cell viability was observed in SGF for $1 \mathrm{~h}$ and SIF for 2 hours; the values of viable cell concentrations were very similar to those obtained for the capsules coated with lecithin (Figure 6). DDAC did not increase significantly $(P>0.05)$ cell survival compared to the free cells, as after $1 \mathrm{~h}$ in SGF the cell concertation was $\sim 5 \log \mathrm{CFU} / \mathrm{mL}$ whereas after $2 \mathrm{~h}$ in SIF no change in the viable cells were detected; these values were considerably lower than those obtained for the capsules coated with DDAC (Figure 6). These results indicate that in the case of coating the capsules with 
DDAC, which was visualised by confocal microscopy (Figure 4), the protection was most likely due the strong alginate-DDAC polymer network formed due to the strong electrostatic interaction between alginate and DDAC, which delayed the penetration of hydrogen ions inside the capsules; this protection was lost when DDAC was used with free cells (Figure 7). On the other hand, in the case of lecithin coated capsules, lecithin rapidly penetrated inside the capsules (Figure 4), where it was most likely able to exert a protective effect to the cells against acid penetration. This is confirmed by the fact that lecithin was able to protect free cells in SGF (Figure 7). To this end, a protective effect towards the viability of probiotic lactic acid bacteria in conditions of high gastric acidity and bile salts was reported in the presence of $2 \%$ (w/v) lecithin by Chen et al. (2012a). It is likely that lecithin due to its zwitterionic character was able to increase the stability of L. plantarum through its integration in the phospholipid bilayer of the bacterial cell membrane thereby preserving the enzyme activity and cytoplasm stability of the cells when present in adverse gastrointestinal conditions (e.g. high acidity, pancreatic enzymes).

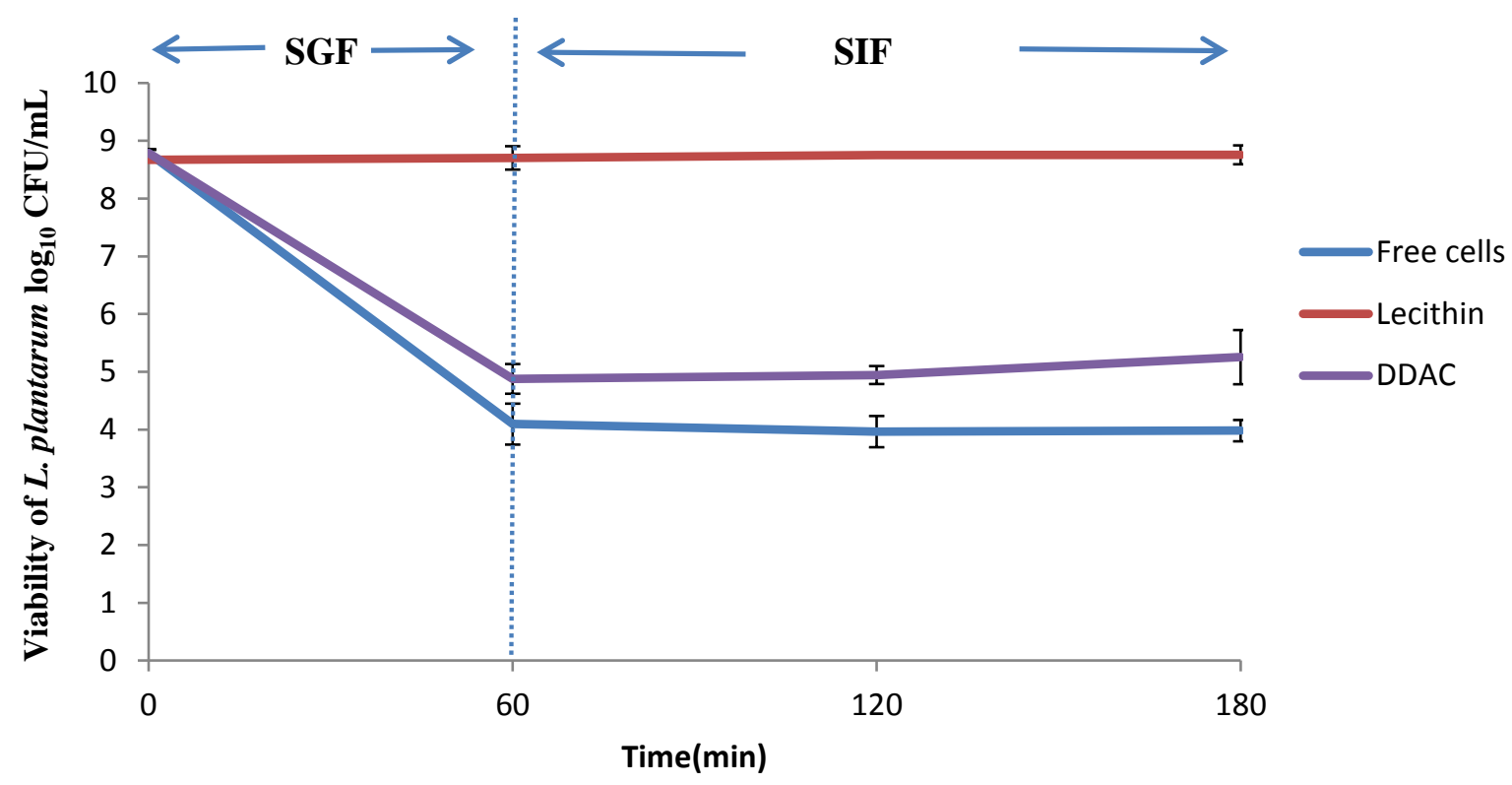

Figure 7 Viability of $L$. plantarum free cells with and without surfactant. The cells were initially exposed to simulated gastric fluid (SGF) at $\mathrm{pH} 2$ for $60 \mathrm{~min}$ followed by exposure to simulated intestinal fluid (SIF) and $\mathrm{pH} 7.2$ for up to $120 \mathrm{~min}$. Data given as mean \pm standard deviation $(n=3)$. 


\section{Conclusions}

547 In this study it was shown that surfactants, depending on their type and properties, can be effectively used for coating alginate capsules containing probiotic bacteria exerting additional protection to the cells. Coating alginate capsules with lecithin, a zwitterionic surfactant,

550

551

552

553

554

555

556

557

558

559

560

561

562

563

564

565

566

567

568

569

570

571

572

573 Bahri, M. A., Hoebeke, M., Grammenos, A., Delanaye, L., Vandewalle, N., \& Seret, A.

574 (2006). Investigation of SDS, DTAB and CTAB micelle microviscosities by electron spin 575

576

577 improved considerably the survival of L. plantarum cells in simulated gastrointestinal fluids compared to non-coated capsules, resulting in complete recovery of viable cells after 1 hour exposure to simulated gastric fluid and two hours in simulated intestinal fluid. Although the interaction between alginate and lecithin was relatively weak, it is likely that the protection was associated with the fact that lecithin was able to penetrate into the capsule rapidly. The cationic surfactant DDAC was not able to penetrate rapidly the capsules, but interacted strongly with alginate primarily due to electrostatic attraction; this most likely resulted in a stronger polymer network which reduced the rate of acid ingress and thus to improved cell survival compared to non-coated capsules. Coating of the capsules with the cationic surfactants hexadecyltrimethylammonium bromide (CTAB) and benzalkonium chloride (BZK), and the anionic surfactants ammonium lauryl sulphate (ALS) and sodium dodecyl sulphate (SDS) resulted in worst survival compared to the uncoated capsules, which was most likely associated with their gradual penetration inside the capsules and their antimicrobial effects.

\section{References}

Abbaszadeh, S., Gandomi, H., Misaghi, A., Bokaei, S., \& Noori, N. (2014). The effect of alginate and chitosan concentrations on some properties of chitosan-coated alginate beads and survivability of encapsulated Lactobacillus rhamnosus in simulated gastrointestinal conditions and during heat processing. Journal of the Science of Food and Agriculture, 94, 2210-2216. resonance. Colloids and Surfaces A - Physicochemical and Engineering Aspects, 290, 206212. 
Bajpai, S. K., \& Sharma, S. (2004). Investigation of swelling/degradation behaviour of alginate beads crosslinked with $\mathrm{Ca} 2+$ and $\mathrm{Ba} 2+$ ions. Reactive and Functional Polymers, 59, 129-140.

Banerjee, D., Chowdhury, R., \& Bhattacharya, P (2017). In-vitro evaluation of targeted release of probiotic Lactobacillus casei (2651 1951 RPK) from synbiotic microcapsules in the gastrointestinal (GI) system: Experiments and modeling. LWT - Food Science and Technology, 83, 243-253.

Bonnaud, M., Weiss, J., \& McClements, D. J. (2010). Interaction of a food-grade cationic surfactant (lauric arginate) with food-grade biopolymers (pectin, carrageenan, xanthan, alginate, dextran, and chitosan). Journal of Agricultural and Food Chemistry, 58, 9770-9777.

Bu, H., Kjoniksen, A.-L., Elgsaeter, A., \& Nystrom, B. (2006). Interaction of unmodified and hydrophobically modified alginate with sodium dodecyl sulfate in dilute aqueous solution: Calorimetric, rheological, and turbidity studies. Colloids and Surfaces A: Physicochemical and Engineering Aspects, 278, 166-174.

Bustamante, M., Gonzalez, M. E., Cartes, A., \& Diez, M. C. (2011). Effect of soya lecithin on the enzymatic system of the white-rot fungi Anthracophyllum discolour. Journal of Industrial Microbiology \& Biotechnology, 100, 701-708.

Carneiro-da-Cunha, M. G., Cerqueira, M. A., Souza, B. W. S., Carvalho, S., Quintas, M. A. C., Teixeira, J. A., \& Vicente, A. A. (2010). Physical and thermal properties of a chitosan/alginate nanolayered pet film. Carbohydrate Polymers, 82, 153-159.

Chamieh, J., Davanier, F., Jannin, V., Demarne, F., \& Cottet, H. (2015). Size characterization of commercial micelles and microemulsions by taylor dispersion analysis. International Journal of Pharmaceutics, 492, 46-54.

Chen, S., Cao, Y., Ferguson, L. R., Shu, Q., \& Garg, S. (2012a). Flow cytometric assessment of the protectants for enhanced in vitro survival of probiotic lactic acid bacteria through simulated human gastro-intestinal stresses. Applied Microbiology and Biotechnology, 95, 345-356. 
613 Chen, S., Zhao, Q., Ferguson, L. R., Shu, Q., Weir, I., \& Garg, S. (2012b). Development of a novel probiotic delivery system based on microencapsulation with protectants. Applied Microbiology and Biotechnology, 93, 1447-1457.

616

617 Chen, J., Wang, Q., Liu, C. M., \& Gong, J. (2017). Issues deserve attention in encapsulating 618 probiotics: Critical review of existing literature. Critical Reviews in Food Science and 619 Nutrition, 57, 1228-1238.

620

621

Cook, M. T., Tzortzis, G., Charalampopoulos, D., \& Khutoryanskiy, V. V. (2011).

Production and evaluation of dry alginate-chitosan microcapsules as an enteric delivery vehicle for probiotic bacteria. Biomacromolecules, 12, 2834-2840.

Cook, M. T., Tzortzis, G., Charalampopoulos, D., \& Khutoryanskiy, V. V. (2012).

Microencapsulation of probiotics for gastrointestinal delivery. Journal of Controlled Release, $162,56-67$.

628

Cords, B. R., Burnett, S. L., Hilgren, J., Finley, M., \& Magnuson, J. (2005). Sanitizers: Branen (Eds.), Antimicrobials in food (3rd ed., pp. 507-572). Boca Raton, FL: Taylor \& Francis.

Cozolli, O. (1997). The roles of surfactants in self-preserving cosmetic formulas. In J. J. Kabara, \& d. S. Orth (Eds.), Preservative-Free and Self-Preserving Cosmetics and Drugs: Principles and Practices (pp. 75-118). New York, Marcel Dekker, Inc.

Cuadros, T. R., Erices, A. A., \& Aguilera, J. M. (2015). Porous matrix of calcium alginate/gelatin with enhanced properties as scaffold for cell culture. Journal of the Mechanical Behavior of Biomedical Materials, 46, 331-342. 
661

Ding, W.K., \& Shah, N.P. (2009). An improved method of microencapsulation of probiotic bacteria for their stability in acidic and bile conditions during storage. Journal of Food Science, 74, 53-61.

Donthidi, A. R., Tester, R. F., \& Aidoo, K. E. (2010). Effect of lecithin and starch on alginate-encapsulated probiotic bacteria. Journal of Microencapsulation, 27, 67-77.

Gbassi, G.K., Vandamme, T., Ennahar, S., E., \& Marchioni, E. (2009). Microencapsulation of Lactobacillus plantarum spp in an alginate matrix coated with whey proteins. International Journal of Food Microbiology, 129, 103-105.

Greenspan, P., Mayer, E. P., \& Fowler, S. D. (1985). Nile red - a selective fluorescent stain for intracellular lipid droplets. Journal of Cell Biology, 100, 965-973.

Hejazi, R., \& Amiji, M. (2003). Chitosan-based gastrointestinaldelivery systems. Journal of Control Release, 89, 151-165.

Hua, S. B., Ma, H. Z., Li, X., Yang, H. X., \& Wang, A. (2010). Ph-sensitive sodium alginate/poly(vinyl alcohol) hydrogel beads prepared by combined $\mathrm{Ca} 2+$ crosslinking and freeze-thawing cycles for controlled release of diclofenac sodium. International Journal of Biological Macromolecules, 46, 517-523.

Huq, T., Fraschini, C., Khan, A., Riedl, B., Bouchard, J., \& Lacroix, M (2017). Alginate based nanocomposite for microencapsulation of probiotic: Effect of cellulose nanocrystal (CNC) and lecithin. Carbohydrate Polymres, 168, 61-69.

Ioannou, C. J., Hanlon, G. W., \& Denyer, S. P. (2007). Action of disinfectant quaternary ammonium compounds against staphylococcus aureus. Antimicrobial Agents and Chemotherapy, 51, 296-306.

Ishikawa, S., Matsumura, Y., Katoh-Kubo, K., \& Tsuchido, T. (2002). Antibacterial activity of surfactants against Escherichia coli cells is influenced by carbon source and anaerobiosis. Journal of Applied Microbiology, 93, 302-309. 
679 Jana, B., Ghosh, S., \& Chattopadhyay, N. (2013). Competitive binding of nile red between 680 lipids and $\beta$-cyclodextrin. Journal of Photochemistry and Photobiology B: Biology, 126, 168110.

682

683 Joondan, N., Jhaumeer-Laulloo, S., \& Caumul, P. (2014). A study of the antibacterial activity 684 of L-Phenylalanine and L-Tyrosine esters in relation to their CMCs and their interactions 685 with 1,2-dipalmitoyl-sn-glycero-3-phosphocholine, DPPC as model membrane. 686 Microbiological Research, 169, 675-685.

687

688

Kabara, J. J., \& Orth, D. S. (1997). Preservative-free and self-preserving cosmetics and 689 drugs: Principles and practices, New York, Marcel Dekker.

690

691 Kundu, P., Ghosh, S., Jana, B., \& Chattopadhyay, N. (2015). Binding interaction of 692 differently charged fluorescent probes with egg yolk phosphatidylcholine and the effect of $\beta$ 693 cyclodextrin on the lipid-probe complexes: A fluorometric investigation. Spectrochimica 694 Acta Part A: Molecular and Biomolecular Spectroscopy, 142, 15-24.

695

696

Labena, A., Hegazy, M. A., Horn, H., \& Muller, E. (2015). The biocidal effect of a novel 697 synthesized gemini surfactant on environmental sulfidogenic bacteria: Planktonic cells and biofilms. Materials Science and Engineering: C, 47, 367-375.

699

Lupo, B., Maestro, A., Porras, M., Gutierrez, J. M., \& Gonzalez, C. (2014). Preparation of 701 alginate microspheres by emulsification/internal gelation to encapsulate cocoa polyphenols. Food Hydrocolloids, 38, 56-65. Martin, M. J., Lara-Villoslada, F., Ruiz, M. A., \& Morales, M. E . (2015). Microencapsulation of bacteria: A review of different technologies and their impact on the probiotic effects. Innovative Food Science \& Emerging Technologies, 27, 15-25.

Neumann, M. G., Schmitt, C. C., \& Iamazaki, E. T. (2003). A fluorescence study of the interactions between sodium alginate and surfactants. Carbohydrate Research, 338, 11091113. 
Nualkaekul, S., Cook, M. T., Khutoryanskiy, V. V., \& Charalampopoulos, D. (2013). Influence of encapsulation and coating materials on the survival of Lactobacillus plantarum and Bifidobacterium longum in fruit juices. Food Research International, 53, 304-311.

Nualkaekul, S., Lenton, D., Cook, M. T., Khutoryanskiy, V. V. \& Charalampopoulos, D. (2012). Chitosan coated alginate beads for the survival of microencapsulated Lactobacillus plantarum in pomegranate juice. Carbohydrate Polymers, 90, 1281-1287.

Obeid, L., El Kolli, N., Dali, N., Talbot, D., Abramson, S., Welschbillig, M., Cabuil, V., \& Bee, A. (2014). Adsorption of a cationic surfactant by a magsorbent based on magnetic alginate beads. Journal of Colloid and Interface Science, 432, 182-189.

Pasparakis, G., \& Bouropoulos, N. (2006). Swelling studies and in vitro release of verapamil from calcium alginate and calcium alginate-chitosan beads. International Journal of Pharmaceutics, 323, 34-42.

Pinazo, A., Manresa, M. A., Marques, A. M., Bustelo, M., Espuny, M. J., \& Perez, L. (2016). Amino acid-based surfactants: New antimicrobial agents. Advances in Colloid and Interface Science, 228, 17-39.

Schramm, L. L., Stasiuk, E. N., \& Marangoni, D. G. (2003). Surfactants and their applications. Annual Reports Section "C" (Physical Chemistry), 99, 3-48.

Simoes, L. D. S., Madalena, D. A., Pinheiro, A. C., Teixeira, J. A., Vicente, A. A., \& Ramos, O. L. (2017). Micro- and nano bio-based delivery systems for food applications: In vitro behaviour. Advances in Colloid and Interface Science, 243, 23-45.

Trabelsi, I., Bejar, W., Ayadi, D., Chouayekh, H., Kammoun, R., Bejar, S., \& Ben Salah, R. (2013). Encapsulation in alginate and alginate coated-chitosan improved the survival of newly probiotic in oxgall and gastric juice. International Journal of Biological Macromolecules, 61, 36-42. 
744 Wang, Y. Z., Wang, W. B., Shi, X. N., \& Wang, A. Q. (2013). A superabsorbent 745 nanocomposite based on sodium alginate and illite/smectite mixed-layer clay. Journal of 746 Applied Polymer Science, 130, 161-167.

747

Williams, R. J., Phillips J. N., \& Mysels, K. J. (1955). The critical micelle concentration of sodium lauryl sulphate at $25^{\circ} \mathrm{C}$. Transactions of the Faraday Society, 51, 728-737.

750

751

Xia, J. D., Xia, Y. M., \& Nnanna, I. A. (1995). Structure-function relationship of acyl amino752 acid surfactants - surface-activity and antimicrobial properties. Journal of Agricultural and Food Chemistry, 43, 867-871.

754

755

Zaeim, D., Sarabi-Jamab, M., Ghorani, B., Kadkhodaee, R., \& Tromp, R. H. (2017).

756 Electrospray assisted fabrication of hydrogel microcapsules by single- and double-stage 757 procedures for encapsulation of probiotics. Food and Bioproducts Processing, 102, 250-259. 758

Zhao, M., Qu, F. N., Wu, Z. J., Nishinari, K., Phillips, G. O., \& Fang, Y. P. (2017).

760 Protection mechanism of alginate microcapsules with different mechanical strength for Lactobacillus plantarum ST-III. Food Hydrocolloids, 66, 396-402.

Zheng, H. Z., Gao, M., Ren, Y., Lou, R. Y., Xie, H. G., Yu, W. T., Liu, X. D., \& Ma, X. J. 764 (2017). An improved pH-responsive carrier based on EDTA-Ca-alginate for oral delivery of 